\title{
RAB27A Gene Mutation
}

National Cancer Institute

\section{Source}

National Cancer Institute. RAB27A Gene Mutation. NCI Thesaurus. Code C158666.

A change in the nucleotide sequence of the RAB27A gene. 